\title{
Citizen Participation in Vietnam's Local Government: Impact on Transparency and Accountability
}

\author{
Thai Thi Thanh Hoa \\ Yonsei University \\ Seoul, South Korea \\ Jean-Claude Garcia-Zamor \\ Florida International University \\ Miami, Florida, United States \\ Email: garciazamor@ hotmail.com
}

Received: Sep. 9, 2017 Accepted: Sep. 26, 2017 Online published: Oct. 23, 2017

doi:10.5296/jpag.v7i4.12044ＵRL: https://doi.org/10.5296/jpag.v7i4.12044

\begin{abstract}
Around the world, a growing crisis of legitimacy and complex problem solving characterize a sense of change in the state-citizen relationship. In Vietnam, the Doi Moi (renovation) process was carried out by the Communist Party of Vietnam (CPV) and the Government of Vietnam (GoV). Public institutions engaged at grassroots level by implementing a decree on "Regulation on Democracy Exercise" with the vision of a participatory society to improve the living standard of the Vietnamese people in general in order to enhance public service specifically. This article conceptualizes the concepts of Citizen Participation, Transparency, and Accountability in Vietnam. In the contested debates of the link between citizen participation and the two governance aspects, transparency and accountability, the article realizes the importance of achieving the balance from both sides of practice, as well as strengthen institutions that can reduce inefficiency and have real effectiveness. The fact that Vietnam just embarked on experimenting with policy initiatives encourages stronger citizen participation. Importantly, citizens participate in a number of elections for their delegates to local and national legislatures. One specific characteristic of public participation in Vietnam is that citizens somewhat are limited in participation by the nomination procedures and restriction in institutions. The article as a brief literature review on citizen participation and establishes the linkages between these three concepts. It reviews policy mechanisms for citizen participation and central-local power relationship. It stresses two main findings after
\end{abstract}


performing sufficient empirical evidences. First, it argues that citizen participation can be an engine of good governance in local public institutions in Vietnam. Once policy window provides the population some space for their participation, it assures a widening scale of an efficient governing system. It founds that transparency and accountability of local governments are two outcomes of citizen participation.

Keywords: citizen participation, transparency, accountability, governance

\section{Introduction}

Around the world, a growing crisis of legitimacy and complex problem solving characterize a sense of change in the state-citizen relationship (Commonwealth Foundation, 1999). One might witness a transition from traditional public participation towards increasingly activated policy windows for socially and politically active citizens. The Sustainable Development Goals (SDGs), known as "Transforming our world: the 2030 Agenda for Sustainable Development", was set by the United Nations (UN) in 2015. The SDGs include 17 goals. One among them is Goal 16, which is more ambitious than ever, promoting "peaceful and inclusive societies for sustainable development, provide access to justice for all and build effective, accountable and inclusive institutions at all levels." (https://sustainabledevelopment.un.org/sdg16). SDGs' Goal 16 mentioned that good governance practices such as citizen participation, transparency, accountability, etc. are strongly recommended to be integrated into political practices in countries around the world in order to make every government accountable to its people. Governments themselves should strive a new aiming for good, transparent and accountable governance. Goal 16 is the institution for public accountability in nations, implying that every country needs to improve their governance systems.

In Vietnam, the Doi Moi (renovation) process was carried out by the Communist Party of Vietnam (CPV) and the Government of Vietnam (GoV). Public institutions engaged at grassroots level by implementing a decree on "Regulation on Democracy Exercise" with the vision of a participatory society to improve the living standard of the Vietnamese people in general in order to enhance public service specifically (Kim et al., 2005). One of the greatest improvement in Vietnam's legitimacy for citizen participation has come to be known as the Grass-Roots Democracy (GRD), which was previously legitimized in 1998 (Decree No. 29/1998/ND-CP), followed by the amended and upgraded into an ordinance in 2007 (GRDO) by the Decree No. 79/2003/ND-CP. GRDO's objective is to institutionalize citizen participation in local governance, especially at the village and communal levels.

The closing gap between citizen and state has been a result of two reactions from institutions (Cornwall et al., 2001). A first reaction is to stress attention on the process of citizen participation. This is the way in which both have and have-not people are given equal voices through public consultation and mobilization. A second reaction is the growing attention emphasizing accountability and transparency of state institutions that enable good governance. To have a sufficient efficiency, each reaction cannot go without the other. For instance, if citizen participation is implemented without accountability and transparency, it leads to a lack of attention to politics, hence the public voices are not applied in policy implementation and 
have no real influence. On the other hand, without citizen participation, governance only strengthens the status quo. Therefore, both sides of the equation, citizen participation-accountability and transparency, are linked.

It has been more than two decades since the central-planning mechanism collapsed in Vietnam. But a chorus of criticism is echoing and blocking the country on its way of renovating public affairs. Is Vietnam a society where corrupted inefficiency is accepted? Gainsborough (2010) is one of those observers who answered "Yes" by describing the length of 20 years in public reform agenda as the one that Vietnam witnessed where only few changes in terms of government's underlying political ideology and practices took place. This means that public affairs mostly act as egoist towards values promoted by neoliberalism: transparency, accountability, participatory governance.

Some quite popular cognizance like the above have asserted that the CPV goes hand in hand with its executive arm (GoV), and maintains an extensive and exclusive control on national public affair. In contrast to that, some have at least enough evidence to justify an acceptable environment for the proliferation of neoliberal values. One important reason is that: in Vietnam, the central-local public administration's structure is reversed compared to some centralized nearby governments like Indonesia, Malaysia, the Philippines, etc. In spite of the fact that the CPV has played a critical role in public affairs, Vietnam's history of warzone has decentralized political power to the local authorities leading to a considerable extent of power relationship's fragmentation (Vasavakul et al., 2009).

In the contested debates of the link between citizen participation and the two governance aspects, transparency and accountability, this article realizes the importance of achieving the balance from both sides of practice, as well as strengthen institutions that can reduce inefficiency and have real effectiveness. At the end of the day, governance is only perceived to be truly effective only if the governance arrangements "are capable of solving the substantive problems that they are set to address" (Fung, 2015).

Transparency and accountability are two key concepts in contemporary democracies and two key components of governance. However, as much as they are discussed in public administration literature, these concepts mean different things to different people. According to Khan (2009, p. 15), "transparency and accountability may sometimes help if both rents and the rent seeking can be potentially legalized", with the "rents" are policy-created benefits, and "rent seeking" is the expenditure of resources by those who want to access those benefits.

Transparency means the ability for policy recipients to easily get access to information and that information is openly provided through public media or other forms. Simply put, transparency is a large extent of public information's disclosure and dissemination. Best (2005) characterized "transparency" as honesty, guilelessness and openness. Transparency is about knowing what public institutions and public officers are doing, as well as justification for their decisions or actions. Many scholars have showed their attention on promoting transparency in governance for higher achievement in development (Vishwanath et al., 1999; Stiglitz, 2002; Kaufmann et al., 2002; OECD, 2006; Anderson et al., 2006), suggesting priorities for actions to improve governance when elite policy-makers influence public policy. 


\section{Macrothink}

The second governance term, accountability itself is similarly important yet ambiguous. Having the same idea, scholars like Jabbra et al. (1988), Jenkins et al. (1999) have stated that accountability has a wide range of connotations. For instance, it can be understood as some people being "held to account", because their acts are appropriate and they take responsibility of their behaviour which could affect a group of people or a public property. Edwards et al. (1996) helped understand accountability as a governance aspect that public employers or politicians are responsible in their jobs and performances, as well as in making their decisions. To hold some powerful decision-makers into account, accountability encompasses a strong potential of having many power relationship at the same time. It is agreed that an effective accountability would require all parties in an accountability contract to believe others and act accordingly. Hence, the relationship of accountability and transparency is fundamental and inseparable.

Citizen participation has proven for a long time to be a strong tool in empowering transparency and accountability. However, in Vietnam, the power of the political party is not necessarily diminished. In fact, Hannah (2007) pointed out that the CPV and the GoV hold a strong grip on civic activities and their civil associations. Furthermore, if the government appears to be genuine in facilitating citizen participation as an integral element of new mode of governance, these efforts do not necessarily empower citizens and push public affairs' efficiency forward. Having the same argument, Beaumont et al., (2008) and Blakeley (2010) pointed out that citizen participation as a new governance arrangement might leads to democratic deficit within governance through a weakening mechanism of transparency and accountability. Citizen participation in enhancing these aspects of governance is in a quest for finding its true impact. In this line of thought, this article analyzes empirically the causality between citizen participation and transparency/accountability in the Vietnam setting. This article also attempts to answer the following research questions: 1) Does citizen participation improve transparency in local governments in Vietnam? and 2) Does citizen participation improve accountability in local governments in Vietnam?

Following these research questions, we develop a conceptual framework to understand them (Figure 1).

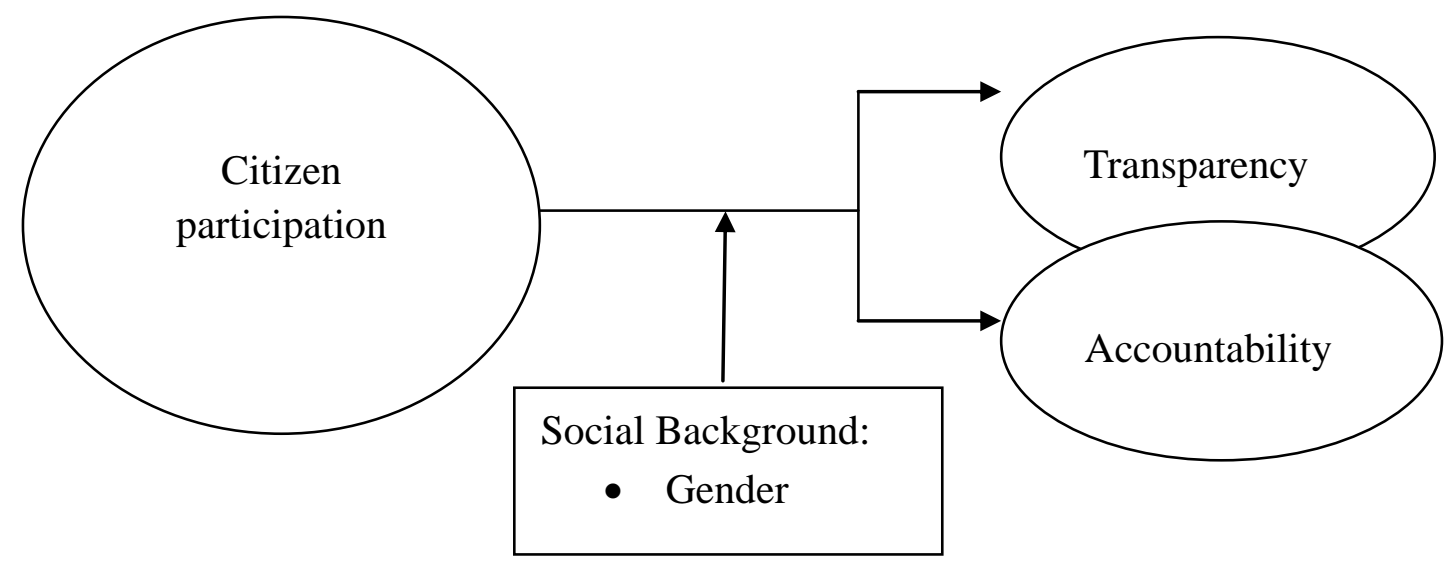

Figure 1. Conceptual Framework 


\section{Macrothink}

Note: Circles represent latent variables. Rectangle represents manifest variable.

This article employs the dataset of The Vietnam Provincial Governance and Public Administration Performance Index (PAPI) to answer the aforementioned questions: How does citizen participation improve transparency and accountability in local governments in Vietnam? As shown in Figure 2, the dependent variables of this article are Transparency and Accountability and the explanatory variable is Citizen Participation. All of these variables are contextualized to the Vietnam context.

\section{Citizen Participation}

- Civic Participation's Knowledge

- Citizenship Rights

- Elections' quality

- Citizens cooperation \& contribution

\section{Transparency}

- Information publicly available

- Quality of information

- Authorities proactively publish information

- Transparent social distribution
Social Background

- Gender

\section{Accountability}

- Relational Accountability

- Complaint mechanism

- People Inspection Board - PIB

- Community Investment Supervision Board - CISB

- Citizens trust towards local leaders \& People's Committee

Figure 2. Analytical Framework

\section{Conceptualizing Citizen Participation, Transparency, and Accountability in Vietnam}

The fact that Vietnam just embarked on experimenting with policy initiatives encourages stronger citizen participation. Importantly, citizens participate in a number of elections for their delegates to local and national legislatures. One specific characteristic of public participation in Vietnam is that citizens somewhat are limited in participation by the nomination procedures and restriction in institutions. However, the cornerstone of GRDO is the local elections, where villagers are able to elect their village heads. One of the most important legal institutions for public participation in Vietnam is the GRDO. As such, citizen 
participation is a fundamental aspect of governance in Vietnam (CECODES et al., 2016).

Governance in Vietnam often is subjected to a lack of transparency. Gainsborough et al. (2009, p. 382) discussed reform agenda in Vietnam suggesting a "Transparency roadmap". While Transparency should be fully taken place in every sector, a designated guideline should be discussed for pilot implementation.

Reducing poverty is arguably the main challenge for developing nations and the globe as a whole. The World Bank revised the Poverty Line, considering a person in extreme poverty if that person lives on or under 1.9 international dollars per day (in terms of purchasing power parity - PPP). In Vietnam, the Ministry of Labor, Invalids and Social Affairs (MOLISA) defined 360,000 VND per person per month (12,000 VND per day, about 0.53 U.S. dollars in IMF exchange rates in May 2017) as acute poverty threshold.

Poverty list is an important recognition of acute poverty of households. This list can enable families and individuals to gain access to social security and a range of social benefits, e.g. free medical insurance, children tuition waivers, etc. The process for a local government to set up a poverty list is multi-staged. This list is subjected to be defined by the head of the village and public agreement by votes in village meetings. After that, the poverty list is publicly posted in village's announcement boards and further stays under scrutiny. Hence, the accuracy and quality of the poverty list is well-related to transparency of local governance.

Fölscher et al. (2012) stated that public participation in budgeting is to have information access and an independent chance for stakeholders to intervene in the budgeting process. According to a UN-HABITAT publication (2004), this participatory form allows direct democracy to flourish at local levels, involving participatory deliberation (Sintomer et al., 2012). Despite its advantages, public participation in budgeting and its impacts are among scholars and practitioners' concerns due to implementing restriction at local levels.

In Vietnam, the GRDO placed a great emphasis on participatory budgeting issues, which is expressed in the right to know of citizens. Publicized commune budget's plan affects local governance positively when citizens enjoy transparent sources of information and use that information in their community involvement.

Under Vietnam context, Transparency in local governance was proved in a study to be the most potentially corrupted in sectors related to rent seeking. To explain Transparency, the authors of this article select land sector according to a study by Vasavakul et al. (2009). In their research, land management was found to be the most vulnerable to corruption due to lack of information. Another research conducted by an independent research organization Development and Policies Research Center (DEPOCEN) (2010) reviewed the central government regulated free flow of land information. The government regulations are embedded in Anti-Corruption Law 2005, the IT Law 2006, the Ordinance on Grassroots Democracy 2007, Project 30, most specifically the Land Law, later elaborated by Decree 84 (2007) and Decree 69 (2009), etc. The DEPOCEN research found that the implementation of these acts vary by local levels and lead to uneven transparency.

A tailored discussion about accountability needs to consider Vietnam's specific political 
characteristics and the nature of its one-party system. Same as transparency, governance in Vietnam often is subjected to a lack of accountability. However, positive signals were observed by qualitative evidence, such as a study by Malesky et al. (2011), which found out that Vietnamese members of Parliament have shown a growing concern of accountability by not casting their votes or even displaying disapproval towards certain disqualified cabinet candidates.

For Mason (2008), the core of accountability is the notion of responsibility. Biermann et al. (2011) also state that the responsibility of accounted individual or group can be achieved through four main dimensions: (1) normative - standard of behavior defined with sufficient precision; (2) relational - accountability relationship between those who have the right to hold to account; (3) decisional - the decisions of whether the expected standard of behavior is met or not; and (4) behavioral - how to sanction the unethical or deviant behavior of those who hold responsibility for accountability.

In Vietnam, relational accountability is especially worth to notice due to one of the main slogans of Vietnamese public officers cán bộ translated summarily as "public officers are servants who always stay close with citizens", which is contrasted to being "distant to the public" (xa rời quần chúng). The relationship from where accountability is pursuit from citizens to public officers is very critical in accountability strategy at local levels.

The revised 2007 GRDO released by the GoV gave birth to the two following Community-Based Organizations (CBOs): The People's Inspection Board (PIB), and the Community Investment Supervision Board (CISB). PIB was actually first introduced in 2004 in the Law on Inspection No. 2/2004/QH11 (Article 11) as a grassroots level accountability mechanism. Later in 2007, this mission was expanded with the introduction of CISB as another grassroots level's governance tool. Two of these CBOs will deliver corruption detections with active involvement from citizens. This is where vertical accountability is achieved in low and lower local level in Vietnam governance.

The Centre for Community Support and Development studies (CECODES), United Nations Development Programs and the Vietnam Fatherland Front (VFF), an umbrella group of pro-government of mass political movements had a common voice (2011) on their perception of these two CBOs. They view them as the most institutionalized with relatively full legal support and most wide-reaching vertical accountability mechanisms in Vietnam local governance.

The PIB mandate is for citizens to supervise the implementation of all laws, regulations and policies by the communal People's Committees - one of the important public authority agencies at local governments. In 2007, PIB's mandate was expanded to become an anti-corruption tool to oversee the implementation of the Anti-corruption Law at the commune and local level, especially in public agencies, public owned businesses, and public officers' acts. The GRDO regulations allow those who serve on PIB's board of directors to have the right of supervision over public budget, public plans (e.g. most well-known are the Poverty List and Land use Plans), other social policies and social benefits. On the other hand, the CISB allows citizens' supervision of investment projects and programs, regardless of the 
capital's origin (e.g. investor can be local level government, or national programs from central government to be locally implemented, district-level government, etc). That will directly affect the community's financial and economics status in communes. It monitors various financial and managerial aspects of investment project, such as effectiveness, efficiency and capital waste, technical and ethical compliance to regulations and regulated processes, procurement, etc.

The PIB and CISB can be established at different governance levels by the joint action of commune level governance authorities and higher level in government. In nowadays common practice, PIB gradually overshadows the CISB in many tasks during those earliest implementation, which is why PAPI uses only indicators of CISB in 2011 not 2016. In 2016, PAPI replaced the CISB indicators by a single indicator that measures citizens' perceptions towards effectiveness of the District People's Committee.

Citizens' satisfaction is also a component of accountability and is based on the common sense assumptions that through interactions with authority leaders, their accountable acts will make citizens feel satisfied.

\section{A Brief Literature Review on Citizen Participation, Transparency and Accountability}

The current stream of public administration theory enlightens the legitimacy crisis of governments and attempts to "bring the citizen back" to the center of the discussion (Fung, 2015; Thomas, 2013; Nabatchi, 2012). Citizen participation has an important implication on governance. As a governing interaction, governance seeks to share power in decision-making process and provide citizens some autonomy and independence for developing the common good through their civic engagement (Jun, 2002). Policymakers usually consider a menu of designated options for citizen participation by enacting and legalizing participatory institutions.

Over the past decade the concept of citizen participation has grown significantly in policy-making process in Vietnam. Broadly saying, citizen participation has been defined as "a process in which individuals take part in decision making in the institutions, programs and environments that affect them" (Heller et al., 1984; Florin et al., 1990). With citizen participation, formulated policies might be more realistically grounded in citizen preferences, the public might become more sympathetic evaluators of the tough decisions that government administrators have to make, and the improved support from the public might create a less divisive, combative populace to govern and regulate (Irvin et al., 2004).

In contemporary Vietnam, citizen participation is conditioned by some changes in state's relationship with its citizenry (Gainsborough, 2010), which allows public officers to consult citizen's opinions. The study of Bingham and the associates (Bingham et al., 2005) called for governments to engage citizen participation into new governance. However, the impact of citizen participation to public governance is unclear. It is influenced by a much more extensive appreciation of public opinion that does not entail a greater capacity for disciplining political elites. Taking two important dimensions of governance that are "transparency" and "accountability", policy decisions are subjected to an increased scrutiny 
and a requirement to be accompanied by rational explanations. However, accountability involves a relationship between citizens and state departments and agencies, but not one that is mediated by a concept of representation connecting citizens to political actors (Rodan et al., 2007).

Citizen participation is the basic right of Vietnamese citizens. It is enshrined in the country's Grass-roots Democracy Ordinance and other legislation. As such, citizen participation is a fundamental aspect of governance in Viet Nam (CECODES et al., 2016). In authors' observation, most literature on citizen participation in the native language is united in one idea: citizen participation is proved to be increasingly powerful in public service. Some international scholars have different perspectives than domestic scholars. Based on this controversy, the authors of this article raise the question whether or not citizen participation is powerful in changing public governance issues. Can citizen participation make change in a very politicized dimension of public affairs? Or to be put in another way, is Vietnam's citizen participation a quality one?

The concept of citizen participation is ubiquitous yet extremely ambiguous. Citizen participation is a contested concept (Rowe et al., 2004). Existing literature has a wide range of definitions. In various situations, it means different things to different people and organizations (Kim et al., 2011). Due to the complexity in trying to define the concept, the authors believe it is important to list out some similar terms.

Firstly, carrying almost similar meaning to citizen participation, public participation is often used interchangeably and those are considered synonyms. However, in this article, the term citizen participation is used strictly because in some context, public participation includes not only citizens as individuals but also organized interests, interest groups and private sector actors.

Secondly, many scholars generally use the word "involvement" in replacement of "participation" or in citizen participation definition. Wang et al. (2007) defines citizen's political participation, as one of the crucial activity of citizen participation. It means "public involvement in expressing preferences for a broad spectrum of important national, regional, or local policies, mainly during the process of selecting political representatives, campaigning, and voting". As defined by Yang et al. (2011), citizen participation is citizen involvement in administrative decision making and management processes. According to them, citizen participation's function is to get citizens involved in issuing regulation, share a responsibility in delivering public goods, and accomplish managerial tasks, etc.

Thirdly, very widely used, "citizen engagement" sometimes carries the same meaning as citizen participation. However, this term particularly implies an intensive level of citizen participation in regular interactions in public administration and political dialogues. But the term does not imply a one-way exchange of idea neither from citizen to government or vice versa. Citizen engagement as a higher level of participation aims for political efforts to revitalize state's democracy. A work of Đurman (2015) contributed to summarize several different dimensions and typology of citizen participation. 
Arnstein (1969) published an article, probably the most well-known and popularly cited in this field, entitled "A ladder of citizen participation" in which she broadly defined citizen participation as a process that brings out citizen's power. Citizen participation ranges from manipulated participation to full citizen control. Moynihan's work (2006) also tried to differentiate types of citizen participation, identifying three types: pseudo, partial and full participation.

From the perspective of deliberative democracy, the value of citizen participation can be found through both its normative and instrumental meanings (Goodin et al., 2006; Hendriks, 2005). Simply put, citizen participation should be understood at the same time as a normative, essential element of life (Moore, 1995; Putnam, 1995); and as a governing tool in order to achieve policy targets (Fung, 2006).

The decisive measurement from a participatory viewpoint and political will of governments is their performance in empowering the population to play an active role in public sphere. This is a daunting task due to some issues of implementation which have emerged consistently in the literature.

Before the modernization plan of 1998 in Vietnam, state was the main employer. In the 1970s and first half of the 1980s most people were employed by the state, either in collective agriculture, in the bureaucracy, or for state-owned enterprises. There was also food rationing. There was tight restriction on people's movement both within the country and outside. What media people were permitted to read or listen to was also tightly controlled, and generally the tentacles of the security apparatus were far-reaching (Long et al., 1981; Canh, 1985).

In terms of the state's relationship with its citizenry, there are signs of both continuity and change. Tight state control over Vietnam's citizen participation, including invasive day-to-day surveillance by the security apparatus, is much less in evidence today. The party-controlled mass organization structure still persists. The party also continues to argue that it operates effectively both as a channel of communication between the state and the society as a source of valued development and citizen participation activity. However, the mass organizations are creaking at the seams, primarily because they appear rather out of date in the context of the rapid social change that has accompanied the reform era. For example, Vietnam's population is not easily categorized as farmers, workers or intellectuals, which is the terminology referred to in the country's constitution (Constitution of Vietnam, 1995). Equally, it is doubtful that all youth, women and business people feel adequately represented by party-regulated groups such as the Youth Union, the Women's Union or the Vietnam Chamber of Commerce and Industry. The proliferation of a wide variety of non-governmental organizations albeit under an uncertain legal framework, further suggests that there is an increasing number of individuals and groups which fall outside party-sanctioned organizational structures (Kerkvliet B. , 2003). All of those factors have facilitated the increasing involvement of citizen participation in public affairs.

Local governments nowadays face a great challenge in providing transparent and accountable services to their citizens and in responding to the complex demands of social and economic development of their local communities. The purpose of this article is to discuss the 
transparency and accountability of local governments by analyzing citizen participation across Vietnam's municipalities and cities. Besides assessing the level of transparency and accountability, the analysis will serve as an empirical process to forecast an indicator of transparency and accountability of local governments.

In the realm of central governance and local governance, citizen participation, transparency and accountability are three main pillars of concern and important phenomena. Transparency and accountability are promoted as the core ingredients of good governance by many international and supranational organizations to determine if a country is qualified for economic cooperation, financial aid or membership in certain organizations (Kim et al., 2005). The UNDP defines good governance as a process that includes nine principles: participation, rule of law, transparency, responsiveness, consensus orientation, equity, effectiveness and efficiency, accountability and strategic vision (Kettani et al., 2008). Strengthening public governance remains a critical priority in policy agendas. And in doing so, transparency and accountability become guiding principles for governments (OECD/OAS, 2002 , p. 37). As context varied, the terms transparency and accountability are both quite elastic to a certain extent. At the core of governance agenda is the battle against corruption, which is related to transparency and accountability. Hence, they are used differently to different context and do not have a precise definition. However, transparency and accountability are identified by Kondo S. (2002, p. 7) in the following manner: "Transparency meaning that reliable, relevant and timely information about the activities of government is available to the public", and "Accountability meaning that it is possible to identify and hold public officials to account for their actions".

Transparency is a two-way communication between government and its social actors which is approached in this article as citizens and citizenships. Simply put, transparency is the information flows between governed and governing actors, and the quality of this information flows. Following the thoughts of Kaufmann et al. (2002, p. 4), Aikins V. (2013, p. 20) further elaborated this term, transparency is not just about giving any information. Transparency should provide the public with empowering information which later support citizens to hold the government accountable. Similarly, the report titled Public sector Accountability and Transparency (OECD/OAS, 2002) advised governments to provide solid legal provisions to enhance transparency through public scrutiny and information access.

If the quality of information is not available or not accessible, transparency turns out to be overrated and losing its values. Etzioni (2010, p. 389) argues that, based upon current research, "transparency cannot fulfill the functions its advocates assign to it, although it can play a limited role in their service". He challenges the notion that "more details means more honesty", emphasizing the problem of the quality of information, usability of information and the competence of intermediary actors which are expected to 'translate' the information for the general public (e.g. the media) but are often not regulated themselves. Hence, it is important to mention the underlying meanings of transparency which according to Best (2005) and Kim et al. (2005, p. 649), includes honesty, guilelessness and openness.

Transparency itself has a lot of promises. Government transparency allows citizens to 
monitor its activities and decisions and to hold the government accountable. It helps to develop a more effective government by infusing information to government activities and thus rendering them more responsive, limiting corruption, other negative practices in public administration, and promoting integrity and ethics in government.

According to Best (2005) and Kim et al. (2005, p. 650) the issue that transparency is not the answer to all governance problems. Even though with the existence of transparency, uncertainties in governance are impossible to be totally eliminated. In addition, political events are vaguely monitored. Along this line, this article seeks to explore one more important and critical dimension of governance, which is accountability. Not by coincidence, accountability together with the term transparency, are watchwords of governance reform around the world.

Accountability has a more malleable meaning as compared to transparency. As a composite concept, it has a range of connotations (Jabbra et al., 1988; Jenkins et al., 1999). It holds the meaning of some party being "held to account". In the context of effective governance, Jalal (1999) and Edwards et al. (1996) referred to accountability as holding public servants to be responsible for their performance and the results of their behavior. Strengthening accountability requires a systematic reform of the state governance. The accountability mechanisms imply both at vertical accountability and horizontal accountability (Santiso, 2001).

While vertical accountability means the accountability between the governed and the governing, horizontal accountability relates to the relationship between different branches of government. Both forms of accountability require the decentralization and de-politicization of public administration. Accountability is thought to be produced in various policy options (Blair, 1998), like local elections, strong and active opposition parties, media, public meetings and formal redress procedures.

\section{The Linkages between Citizen Participation, Transparency, and Accountability}

There have been conflicted evidences that link citizen participation to both greater and lower quality of governance. First of all, citizen participation definition cannot be a conceptual straitjacket across varied nations' contexts. However, its normative theoretical perception is that the populations will be able to keep an eye on the governance regimes and contribute to enhance their efficiency and oust corruption. This will tend to make the quality of governance higher in the long term.

Many qualitative studies observed that governance involves people and the process they participate (Bingham et al., 2005) and through this process, governance quality is strengthen (Macedo et al., 2004; Dryzek et al., 2003; Gutmann et al., 1996; Macedo, S. (Ed.)., 1999; Polletta, 2012; Cooper et al., 1984; Pateman, 1970). Backing up this idea, Goetzmann (2000) observed that the cost of lack of institutions for citizen participation can raise government's cost. His study showed that in financial crisis, there is a dictatorship where the ordinary citizens have no voice and are financially hurt. As a consequence, without institutions of transparency, the citizens could not fully aware of the risk they were facing or held public 
servants accountable. More recently, Aikins V. (2013) found evidences in the budget process in Ghana to prove that through the media, citizen participation improves transparency and accountability in the long run.

However, another group of scholars found out that a combination between citizen participation and governance capacity is hard to create. A curvilinear causal relationship is found between administrative performance (which one dimension among them is transparency) and public inclusion policy-making process (Bäck et al., 2008). That study helps to explain other researchers' observations of a global tendency toward a growing gap between the two concepts. Interestingly, transparent quality of governments in some strong authoritarian states is found to be higher than in the states that are relatively partially democratized. In a more classical research using traditional perception of participation, Morrell (1999) also found that a distinctive difference among participation conditions in policy decision-making leads to no difference of citizenry's trust in governments' legitimacy. Gangl (2000) supported Morrell (1999) in her independent research on different subject of procedural justice. She stated that the "people have voice" process produced no significance in perceived legitimacy, meaning no accountability was found to be related. In an extensive social experiment conducted by Hibbing et al. (2002), the findings are in the same side of the argument. They found that there is no significant patterns proving that voice of citizens standing alone make a difference in subjects' perceptions of fairness of the decision maker. Only little evidence is found to prove the opposite pattern of a positive impact when extra conditions appeared in the experiment.

Even though the cases above do not fully captivate the whole picture of citizen participation and its impact on good governance, nonetheless these evidences give us the idea that the combination of citizen participation and good governance depend on the context and are influenced by the participatory institutions. This variation affects the participatory process and decides who participates, how is the connection to the decision makers, the governing rulers, substantive outcomes, etc. This is well-recorded in an article of Fung A. (2015) where the author mentions again that circumstances differentiate citizen participation in governance.

\section{Policy Mechanism for Citizen Participation and Central - Local Power Relationship in Vietnam}

The GRDO is the government response to a call for better governance practices at the local level. This legal expression allows grassroots democratization to spread at the commune level to improve the laws that facilitate citizens' complaints and denunciations of corrupt local officials. The GRDO functions to achieve four main objectives.

First, to enhance budget transparency and allocation;

Second, to increase citizen participation in decision-making;

Third, to increase the role of the public in guarding and managing local government via complaints and denunciation provisions; and

Fourth, to designate the village level as the basic unit to achieve its objectives. 
The GRDO is also considered as an empowerment strategy of central government to "kill two birds with one stone". Those goals are to democratize local level through policy education for the ordinary citizens. They help gain better control over local government and influence the behavior of corrupted public officials.

Policy windows for positive change may start from citizens' complaints. Mechanisms for the complaining process are completed when GRDO allows citizens' complaints and denunciations to be heard by public servants at local villages and communes. According to Burall et al. (2005), good governance is underpinned when the effective complaints and redress processes support public accountability principles. Furthermore, effectiveness of the complaining process should be in place so that citizens are treated not only as consumers in the ideology of consumerism, but also as advocates to ensure public sector accountability and achieve good governance (Brewer, 2007).

\section{Conclusion - Research Contributions and Policy Implications}

In this article the authors have repeatedly stressed the importance of the impact of citizen participation on governance and on transparency and accountability. Citizen plays several roles in the governance structure that are aimed at improving good governance. Hence, it is significant to specify the existence of whether or not the impact is inherent in the context of Vietnam.

After examining the relevant literature, the article has stressed two main findings. First, the authors have argued that citizen participation can be an engine of good governance in local public institutions in Vietnam. Once policy window provides the population with some space for their participations, it assures a widening scale of an efficient governing system. Undoubtedly, active citizen participation brings many benefits that will reflect some shifting characteristics of the whole social structure. The second finding, based also on an analysis of the literature, found that transparency and accountability of local governments are two outcomes of citizen participation.

The article has also made a contribution to the study of participatory governance and democracy in developing countries. Its findings can be used to argue that even under rigid political structure, citizen participation, when practiced in local commune or at the village level, would shed lights on democratic governance. It is a case study that identifies the factors contributing to participatory governance in Vietnam.

The article is based on an assumption that governance in a nation-state is dynamic in different administrative levels. Clearly, it is better to focus our current vision to the local level when it comes to discussing governance. However, central government is still the crucial actor when thinking about governance in a conventional way. Hence, central government should be the next level for evaluating governance which is undeniably dynamic. Without discarding the importance of states, the authors recommend that future research be directed to governance at the national level. 


\section{Acknowledgement}

Thai Thi Thanh Hoa received a Bachelor in Business Administration from Hue University in Vietnam and a Master in Public Administration from Yonsei University in Korea. She is grateful to Professor Kim Pan Suk of Yonsei University for his comments about her research and to the Vietnam Provincial Governance and Public Administration Performance Index (PAPI) for providing her with valuable data for her research. Jean-Claude Garcia-Zamor is a professor of public administration at Florida International University.

\section{Reference}

Aikins, V. (2013). Democratic Governance and Citizen Participation: The Role of the Media in Ghana's Budget Preparation Process. Master Thesis, International Institute of Social Studies, The Hague, The Netherlands.

Anderson, J. H., \& Gray, C. W. (2006). Anticorruption in transition 3: who is succeeding... and why? World Bank Publications. https://doi.org/10.1596/978-0-8213-6692-9

Arnstein, S. R. (1969). A ladder of citizen participation. Journal of the American Institute of planners, 35(4), 216-224. https://doi.org/10.1080/01944366908977225

Bäck, H., \& Hadenius, A. (2008). Democracy and state capacity: exploring a J -shaped relationship. Governance, 21(1), 1-24. https://doi.org/10.1111/j.1468-0491.2007.00383.x

Beaumont, J., \& Loopmans, M. (2008). Towards radicalized communicative rationality: resident involvement and urban democracy in Rotterdam and Antwerp. International Journal of Urban and Regional Research, 32(1), 95-113. https://doi.org/10.1111/j.1468-2427.2008.00780.x

Best, J. (2005). The limits of transparency: ambiguity and the history of international finance. Cornell University Press.

Biermann, F., \& Gupta, A. (2011). Accountability and legitimacy in earth system governance: a research framework. Ecological economics, 70(11), 1856-1864. https://doi.org/10.1016/j.ecolecon.2011.04.008

Bingham, L. B., Nabatchi, T., \& O'Leary, R. (2005). The new governance: Practices and processes for stakeholder and citizen participation in the work of government. Public administration review, 65(5), 547-558. https://doi.org/10.1111/j.1540-6210.2005.00482.x

Blair, H. (1998). Spreading power to the periphery. US Agency for International Development Center for Development Information and Evaluation.

Blakeley, G. (2010). Governing ourselves: citizen participation and governance in Barcelona and Manchester. International Journal of Urban and Regional Research, 34(1), 130-145. https://doi.org/10.1111/j.1468-2427.2010.00953.x

Brewer, B. (2007). Citizen or customer? Complaints handling in the public sector. International Review of Administrative Sciences, 73(4), 549-556. https://doi.org/10.1177/0020852307083457 
Burall, S., \& Neligan, C. (2005). The Accountability of International Organizations. Berlin, Germany: Global Policy Institute.

Canh, N. V. (1985). Vietnam under Communism, 1975-1982. Stanford CA: Hoover Institution Press.

CECODES, VFF-CRT \& UNDP. (2016). The Viet Nam Governance and Public Administration Performance Index (PAPI) 2015. Hanoi, Vietnam: A Joint Policy Research Paper by Centre for Community Support and Development Studies (CECODES), Centre for Research and Training of the Viet Nam Fatherland Front (VFF-CRT), and United Nations Development Programme (UNDP).

Commonwealth Foundation. (1999). The Way Forward: Citizens, Civil Society and Governance in the new Millennium. Commonwealth Foundation. London: Commonwealth Foundation.

Constitution of Vietnam. (1995). Constitution of Vietnam: 1946-1959-1980-1992. Hanoi: Gioi Publishers.

Cooper, T. L., \& Gulick, L. (1984). Citizenship and professionalism in public administration. Public Administration Review, 44, 143-151. https://doi.org/10.2307/975554

Cornwall, A., \& Gaventa, J. (2001). Bridging the gap: citizenship, participation and accountability. PLA notes, 40(2001), 32-35.

Dryzek, J. S., \& List, C. (2003). Social choice theory and deliberative democracy: a reconciliation. British Journal of Political Science, 33(1), 1-28. https://doi.org/10.1017/S0007123403000012

Đurman, P. (2015). Citizen participation in public administration: the case of Croatian local government. Faculty of Law, University of Zagreb.

Edwards, M., \& Hulme, D., eds. (1996). Beyond the magic bullet: NGO performance and accountability in the post-cold war world (p. 1). West Hartford, CT: Kumarian Press.

Etzioni, A. (2010). Moral dimension: Toward a new economics. Simon and Schuster.

Florin, P., \& Wandersman, A. (1990). An introduction to citizen participation, voluntary organizations, and community development: Insights for empowerment through research. American Journal of Community Psychology, 18(1), 41-54. https://doi.org/10.1007/BF00922688

Fölscher, A., \& Gay, E. (2012). Fiscal transparency and participation in Africa: A study report. Pretoria, South Africa: The Collaboration Africa Budget Reform Initiative (CABRI).

Fung, A. (2006). Varieties of participation in complex governance. Public administration review, 66(1), 66-75. https://doi.org/10.1111/j.1540-6210.2006.00667.x

Fung, A. (2015). Putting the public back into governance: The challenges of citizen participation and its future. Public Administration Review, 75(4), 513-522. 
https://doi.org/10.1111/puar.12361

Gainsborough, M. (2010). Present but not powerful: neoliberalism, the state, and development in Vietnam. Globalizations, $\quad 7(4), \quad 475-488$. https://doi.org/10.1080/14747731003798435

Gainsborough, M. (2010). Vietnam: Rethinking the state. Zed Books.

Gainsborough, M., Dinh, D. N., \& Phuong, T. T. (2009). Corruption, Public Administration Reform and Development: Challenges and Opportunities as Viet Nam moves towards Middle-Income Status. In Reforming Public Administration in Vietnam (p. 379 - 430). Hanoi: The National Political Publishing House.

Gangl, A. (2000). It isn't Fair: Do Perceptions of Procedural Justice in Evaluations of Congress matter more than getting what you want? Annual Meeting of the Midwest Political Science Association. Chicago, IL.

Global Campaign on Urban Governance. (2004). 72 frequently asked questions about participatory budgeting. UN-HABITAT.

Goetzman, W. (2000). Democracy Before Debt. The Good Society, 9(3), 67-67.

Goodin, R. E., \& Dryzek, J. S. (2006). Deliberative impacts: the macro-political uptake of mini-publics. Politics \& society, 34(2), 219-244. https://doi.org/10.1177/0032329206288152

Gutmann, A., \& Dennis, T. (1996). Democracy and Disagreement. Cambridge, MA: Harvard University Press.

Hannah, J. (2007). Local non-government organizations in Vietnam: development, civil society and state-society relations. Seattle, WA: Ph.D. Dissertation. University of Washington.

Heller, K., Price, R., Reinharz, S., Wanderson, A., \& D’Aunno, T. (1984). In Psychology and community change: Challenges of the future (2nd ed.). Pacific Grove, CA: Brooks/Cole Publishing Company.

Hendriks, C. M. (2005). Participatory storylines and their influence on deliberative forums. Policy sciences, 38(1), 1-20. https://doi.org/10.1007/s11077-005-0870-3

Hibbing, J. R., \& Theiss, M. E. (2002). Stealth democracy: Americans' beliefs about how government should work. Cambridge University Press. https://doi.org/10.1017/CBO9780511613722

Irvin, R. A., \& Stansbury, J. (2004). Citizen participation in decision making: is it worth the effort? Public administration review, 64(1), 55-65. https://doi.org/10.1111/j.1540-6210.2004.00346.x

Jabbra, J. G., \& Dwivedi, O. P. (1988). Public service accountability: A comparative perspective. Hartford, CT: Kumarian Press.

Jalal, J. (1999). Democratic Decentralization in Urban Governance: A Comparative Study of 
Two Indian Cities. Institute of Development Studies Bulletin, 32(1).

Jenkins, R., \& Goetz, A. M. (1999). Accounts and accountability: theoretical implications of the right-to-information movement in India. Third world quarterly, 20(3), 603-622. https://doi.org/10.1080/01436599913712

Jun, J. S. (2002). New Governance in Civil Society Changing Responsibility of Public Administration. Rethinking Administrative theory: The challenge of the new Century, 289-307.

Kaufmann, D., \& Kraay, A. (2002). Growth without governance. World Bank. https://doi.org/10.1353/eco.2002.0016

Kerkvliet, B. (2003). Authorities and the people: an analysis of state-society relations in Vietnam. In Postwar Vietnam: Dynamics of a transforming society (Vol. 16, p. 27).

Kettani, D., Moulin, B., Gurstein, M., \& El Mahdi, A. (2008). E-government and local good governance: a pilot project in Fez, Morocco. The Electronic Journal of Information Systems in Developing Countries, 35.

Khan, M. (2009). Pro-Growth Anti-corruption and Governance Reforms for Viet Nam: Lessons from East Asia. Public Administration Reform and Anti-Corruption: A series of policy discussion papers. Ha Noi, Viet Nam. Available at http://www.undp.org.vn/undpLive/detail/publications/publicationdetails?contentId=3295\&lan guageId=1: United Nations Development Programme.

Kim, P. S. (2011). Civic engagement, politics and policy in South Korea: Significant developments but a considerable way to go. Public Administration and Development, 31(2), 83-90. https://doi.org/10.1002/pad.595

Kim, P. S., Halligan, J., Cho, N., Oh, C. H., \& Eikenberry, A. M. (2005). Toward participatory and transparent governance: report on the Sixth Global Forum on Reinventing Government. Public Administration Review, 65(6), 646-654. https://doi.org/10.1111/j.1540-6210.2005.00494.x

Kondo, S. (2002). Fostering dialogue to strengthen good governance. In Public Sector Transparency and Accountability: Making it Happen. Paris: OECD Publishing.

Long, N., \& Kendall, H. H. (1981). After Saigon Fell: Daily Life under the Vietnamese Communists. Berkeley CA: Institute of East Asian Studies.

Macedo, S. (Ed.). (1999). Deliberative politics: Essays on democracy and disagreement. Oxford University Press.

Macedo, S., Alex-Assensoh, Y. M., Berry, J. M., \& Brintnall, M. (2004). Democracy at Risk: Renewing the Political Science of Citizenship. American Political Science Association's Standing Committee on Civic Education and Engagement.

Malesky, E., \& Schuler, P. (2011). The Single - Party Dictator's Dilemma: Information in Elections without Opposition. Legislative Studies Quarterly, 36(4), 491-530. 
https://doi.org/10.1111/j.1939-9162.2011.00025.x

Mason, M. (2008). The governance of transnational environmental harm: addressing new modes of accountability/responsibility. Global Environmental Politics, 8(3), 8-24. https://doi.org/10.1162/glep.2008.8.3.8

Moore, M. (1995). Creating public value. Cambridge: Mass, Harvard.

Morrell, M. E. (1999). Citizen's evaluations of participatory democratic procedures: Normative theory meets empirical science. Political Research Quarterly, 52(2), 293-322. https://doi.org/10.1177/106591299905200203

Moynihan, D. P. (2003). Normative and instrumental perspectives on public participation: Citizen summits in Washington, DC. The American Review of Public Administration, 33(2), 164-188. https://doi.org/10.1177/0275074003251379

Nabatchi, T. (2012). Putting the "public" back in public values research: Designing participation to identify and respond to values. Public Administration Review, 72(5), 699-708. https://doi.org/10.1111/j.1540-6210.2012.02544.x

Nguyen, N., Nguyen, D., Tran, T., Kirby, P., \& Phan, T. (2010). Survey Report on Information Disclosure of Land Management regulations. Hanoi: Vietnam Development Information Center (VDIC).

OECD/OAS. (2002). Public Sector Transparency and Accountability: Making it Happen. Paris: OECD Publishing.

Organization of Economic Cooperation and Development (OECD). (2006). The OECD Fights Corruption. Paris, France: OECD publications.

Pateman, C. (1970). Participation and democratic theory. Cambridge University Press. https://doi.org/10.1017/CBO9780511720444

Polletta, F. (2012). Freedom is an endless meeting: Democracy in American social movements. University of Chicago Press.

Putnam, R. D. (1995). Bowling alone: America's declining social capital. Journal of democracy, 6(1), 65-78. https://doi.org/10.1353/jod.1995.0002

Rodan, G., \& Jayasuriya, K. (2007). The technocratic politics of administrative participation: case studies of Singapore and Vietnam. Democratization, 14(5), 795-815. https://doi.org/10.1080/13510340701635662

Rowe, G., \& Frewer, L. J. (2004). Evaluating public-participation exercises: a research agenda. Science, technology, \& human values, 29(4), 512-556. https://doi.org/10.1177/0162243903259197

Santiso, C. (2001). Good Governance and Aid Effectiveness: The World Bank and Conditionality. Georgetown Public Policy Review, 7, 1-22.

Sintomer, Y.; Herzberg, C.; Rocke, A.; \& Allegretti, G. (2012). Transnational models of 


\section{Macrothink}

Journal of Public Administration and Governance ISSN 2161-7104 2017, Vol. 7, No. 4

citizen participation: The case of participatory budgeting. Journal of Public Deliberation, $8(2), 1-32$.

Stiglitz, J. (2002). Transparency in government. In The Right to Tell (p. 27).

Thomas, J. C. (2013). Citizen, customer, partner: Rethinking the place of the public in public management. Public Administration Review, 73(6), 786-796. https://doi.org/10.1111/puar.12109

UNDP, CECODES \& the Vietnam Fatherland Front. (2011). The Viet Nam Provincial Governance and Public Administration Performance Index (PAPI) 2010. Hanoi, Vietnam: CECODES.

Vasavakul, T., Le, T., \& Le, V. (2009). Public administration and economic development in Viet Nam: Reforming the public administration for the 21st century. In Reforming Public Administration in Viet Nam (p. 41).

Vishwanath, T., \& D. Kaufmann. (1999). Towards Transparency in Finance and Governance. World Bank.

Wang, X., \& Wan, W. M. (2007). When public participation in administration leads to trust: An empirical assessment of managers' perceptions. Public Administration Review, 67(2), 265-278. https://doi.org/10.1111/j.1540-6210.2007.00712.x

Yang, K., \& Pandey, S. K. (2011). Further dissecting the black box of citizen participation: When does citizen involvement lead to good outcomes? Public Administration Review, 71(6), 880-892. https://doi.org/10.1111/j.1540-6210.2011.02417.x

\section{Copyright Disclaimer}

Copyright for this article is retained by the author(s), with first publication rights granted to the journal.

This is an open-access article distributed under the terms and conditions of the Creative Commons Attribution license (http://creativecommons.org/licenses/by/4.0/). 